\title{
ANALISIS TINGKAT PEMAHAMAN BERLALU LINTAS PADA SISWA SEKOLAH DASAR DENGAN DAN TANPA EDUKASI DI KABUPATEN BANTUL YOGYAKARTA
}

\author{
Agung Eko Saputro 1 , S. Priyanto ${ }^{2}$, M. Z. Irawan ${ }^{3}$ \\ Departemen Teknik Sipil dan Lingkungan, Universitas Gadjah Mada, Yogyakarta \\ *Corresponding author: agungbkd08@gmail.com
}

\begin{abstract}
ABSTRAK
Penelitian ini bertujuan untuk mengidentifikasi dan membandingkan perilaku siswa sekolah dasar yang telah menerima edukasi keselamatan lalu lintas dengan siswa yang belum menerima edukasi keselamatan berlalu lintas. Penelitian ini dilakukan pada 4 Sekolah Dasar yaitu SD Negeri Krebet, SD Puluhan, SD Priyan dan SD Bendosari Kabupaten Bantul dengan pertimbangan bahwa Sekolah Dasar di Kabupaten Bantul paling banyak menerima edukasi tentang keselamatan lalu lintas Safety for Children yang diselenggarakan oleh Gachon University bekerjasama dengan Universitas Gadjah Mada, Dinas Perhubungan, Kepolisian Daerah Istimewa Yogyakarta, Dinas Pendidikan dan Kebudayaan dan Koica. Jenis data yang digunakan adalah data primer dan data sekunder. Penyebaran kuesioner pada siswa dilakukan untuk memperoleh data kuantitatif. Kuesioner yang dibagikan melalui google form dan pengisian oleh siswa dapat dibantu oleh orang tua/wali murid. Berdasarkan anlisis penelitian diketahui bahwa siswa yang telah mendapatkan pendidikan keselamatan berlalulintas lebih memahami praktik dan pemahaman berlalulintas dibandingkan dengan siswa yang tidak mendapatkan pendidikan keselamatan berlalulintas, meskipun perbandingan nilainya tidak signifikan.
\end{abstract}

Kata kunci: Perilaku berlalu lintas anak, Edukasi keselamatan lalu lintas, Pemahaman berlalu lintas anak

\begin{abstract}
This study aims to identify and compare the behavior of elementary school students who have received traffic safety education with students who have not received traffic safety education. This research was conducted in 4 elementary schools namely SD Negeri Krebet, SD Puluhan, $S D$ Priyan and SD Bendosari Bantul regency with the consideration that elementary schools in Bantul district receive the most education about traffic safety safety for Children organized by Gachon University in collaboration with Gadjah Mada University, the Transportation Agency, the Yogyakarta Special Region Police, the Education and Culture Office and Koica. The types of data used are primary and secondary data. The distribution of questionnaires to students was carried out to obtain quantitative data. Questionnaires shared through google form and filled in by students can be assisted by parents/ parents. Based on the anlysis of research it is known that students who have obtained a passing safety education better understand the practice and understanding of passing traffic compared to students who do not get a passing safety education, although the comparison of grades is not significant.
\end{abstract}

Keywords: Child traffic behavior, Traffic safety education, Understanding child traffic 


\section{PENDAHULUAN}

\section{Latar Belakang}

Beberapa dekade ini terjadi peningkatan volume lalu lintas di banyak tempat. Peningkatan ini mengakibatkan kepadatan, yang memicu terjadinya banyak pelanggaran. Selain itu ditambah dengan kurangnya kesadaran untuk menggunakan alat-alat keselamatan. Hal-hal ini mengakibatkan terjadinya banyak kecelakaan yang memberikan dampak buruk berupa luka-luka hingga kematian. Kecelakaan dapat terjadi pada setiap orang, baik yang diakibatkan karena pelanggaran maupun kelalaian orang lain. Sehingga, setiap orang sudah seharusnya berperilaku yang baik saat berlalulintas. Hal ini sangat mudah dterapkan bagi orang dewasa, karena sudah mampu beretika yang baik saat berlalu lintas. Berbeda halnya dengan anak-anak, yang mana belum dapat beretika dengan baik saat di jalan, sehinga tidak jarang terjadi kecelakaan pada anak. Kelalaian anak-anak terjadi akibat kurangnya pendidikan yang diterima. Sehingga, anak-anak perlu mendapatkan pendididkan keselamatan berlalu lintas. Dan memastikan bahwa mereka yang telah mendapatkan pendidikan, menerapkannya ketika berlalu lintas. Sehingga, angka kecelakaan khususnya pada anak-anak dapat ditekan.

\section{Rumusan Masalah}

Bagaimana perbedaan praktik dan perilaku berlalu lintas siswa Sekolah Dasar yang telah mendapatkan pendidikan keselamatan berlalu lintas, dengan siswa yang belum/tidak mendapatkan pendidikan keselamatan.

\section{Tujuan Penelitian}

1. Mengidentifikasi praktik dan pemahaman berlalu lintas oleh siswa yang telah mendapatkan pendidikan keselamatan berlalulintas.

2. Mengidentifikasi praktik berlalulintas oleh siswa yang belum/tidak mendapatkan pendidikan keselamatan berlalu lintas.

3. Membandingkan perilaku siswa di Sekolah Dasar yang telah mendapatkan pendidikan keselamatan berlalulintas dengan siswa yang belum/tidak mendapatkan keselamatan berlalulintas.

\section{Batasan Masalah}

1. Jangkauan wilayah pada penelitian ini dibatasi pada lingkup Sekolah Dasar di wilayah Kabupaten Bantul Daerah Istimiwa Yogyakarta.

2. Sekolah Dasar yang dipilih adalah sekolah yang telah menerima pendidikan keselamatan lalu lintas dan Sekolah Dasar di Kabupaten Bantul.

3. Responden dalam penelitian ini adalah guru, wali murid dan siswa kelas Sekolah Dasar yang telah menerima pendidikan keselamatan berlalu lintas. 


\section{METODE PENELITIAN}

\section{Lokasi Penelitian}

Penelitian ini dilakukan dengan pertimbangan bahwa Sekolah Dasar di Kabupaten Bantul paling banyak menerima edukasi tentang keselamatan lalu lintas Safety for Children yang diselenggarakan oleh Gachon University bekerjasama dengan Universitas Gadjah Mada, Dinas Perhubungan, Kepolisian Daerah Istimewa Yogyakarta, Dinas Pendidikan dan Kebudayaan dan Koica. Penelitian dilakukan pada 4 Sekolah Dasar yaitu SD Negeri Krebet, SD Puluhan, SD Priyan dan SD Bendosari.

\section{Waktu Penelitian}

Penelitian dilaksanakan pada Bulan Januari 202. Penelitian dan pengambilan data sebagian besar dilakukan dengan online via google form karena Bulan April 2020 sekolah mulai dilaksanakan secara online dampak dari penyebaran Virus Covid-19 di Indonesia.

\section{Data Primer}

Data primer merupakan data yang didapat dari kuesioner yang ditujukan oleh siswa-siswi Sekolah Dasar di Kabupaten Bantul sebagai responden.

\section{Data Sekunder}

Data sekunder yaitu data penunjang yang dibutuhkan terkait penelitian, seperti data jumlah sekolah dasar dan siswa di Kabupaten Bantul, data angka kecelakaan lalu lintas di Kabupaten Bantul dan lain sebagainya.

\section{HASIL DAN PEMBAHASAN}

\section{Uji Validitas}

Nilai r yang dihasilkan dibandingkan dengan $r$ tabel dengan tingkat signifikasi $95 \%(\alpha=0,05)$. Apabila nilai $r$ hitung lebih besar dari $r$ tabel, maka instrumen yang berupa kuesioner yang digunakan dapat dikatakan valid. Nilai $D F$ pada penelitian ini adalah $\mathrm{DF}=\mathrm{N}-2, \mathrm{~N}$ berjumlah sebanyak 50 responden maka nilai $\mathrm{DF}=48$ dengan tingkat signifikan 0,05 pada uji dua arah diperoleh nilai $r$ table yaitu 0,2787 . Apabila hasil uji validitas menunjukkan $r$ hitung $\geq r$ tabel, maka Ho ditolak dan Ha diterima artinya butir pertanyaan kuesioner dinyatakan valid.

Tabel 1. Hasil Validitas Perilaku Disip;in Pada Siswa yang Sudah Penah Menerima Pendidikan Lalu Lintas

\begin{tabular}{|c|l|c|c|c|c|}
\hline Variabel & \multicolumn{1}{|c|}{ Butir Pertanyaan } & rhitung & rtabel & $\begin{array}{c}\text { Hasil } \\
\text { Hipotesis }\end{array}$ & Keterangan \\
\hline P1 & Berjalan di sisi paling tepi & 0,4556 & 0,2787 & $\begin{array}{c}\text { Ha } \\
\text { diterima }\end{array}$ & Valid \\
\hline P2 & Berjalan kaki di trotoar & 0,4580 & 0,2787 & $\begin{array}{c}\text { Ha } \\
\text { diterima }\end{array}$ & Valid \\
\hline P3 & $\begin{array}{l}\text { Menoleh ke kanan kiri } \\
\text { serta berhenti sejenak } \\
\text { sebelum menyeberang }\end{array}$ & 0,4556 & 0,2787 & $\begin{array}{c}\text { Ha } \\
\text { diterima }\end{array}$ & Valid \\
\hline
\end{tabular}




\begin{tabular}{|c|l|c|c|c|c|}
\hline P4 & $\begin{array}{l}\text { Menyeberang di zebra } \\
\text { cross }\end{array}$ & 0,5681 & 0,2787 & $\begin{array}{c}\text { Ha } \\
\text { diterima }\end{array}$ & Valid \\
\hline P5 & $\begin{array}{l}\text { Menyeberang jalan saat } \\
\text { kondisi aman }\end{array}$ & 0,4114 & 0,2787 & $\begin{array}{c}\text { Ha } \\
\text { diterima }\end{array}$ & Valid \\
\hline P6 & $\begin{array}{l}\text { Meminta bantuan petugas } \\
\text { atau orang dewasa jika } \\
\text { kesulitan menyeberang }\end{array}$ & 0,4816 & 0,2787 & $\begin{array}{c}\text { Ha } \\
\text { diterima }\end{array}$ & Valid \\
\hline P7 & $\begin{array}{l}\text { Bersepeda di lajur khusus } \\
\text { sepeda }\end{array}$ & 0,8619 & 0,2787 & $\begin{array}{c}\text { Ha } \\
\text { diterima }\end{array}$ & Valid \\
\hline P8 & $\begin{array}{l}\text { Menggunakan helm saat } \\
\text { akan dibonceng sepeda } \\
\text { motor }\end{array}$ & 0,5810 & 0,2787 & $\begin{array}{c}\text { Ha } \\
\text { diterima }\end{array}$ & Valid \\
\hline P9 & $\begin{array}{l}\text { Memakai seat belt } \text { saat } \\
\text { berkendara menggunakan } \\
\text { mobil }\end{array}$ & 0,6439 & 0,2787 & $\begin{array}{c}\text { Ha } \\
\text { diterima }\end{array}$ & Valid \\
\hline
\end{tabular}

Dari tabel diketahui bahwa uji validitas yang dilakukan pada butir pertanyaan kuesioner menghasilkan nilai korelasi yaitu $\mathrm{r}$ hitung $\geq \mathrm{r}$ tabel, artinya Ho ditolak dan Ha diterima. Sehingga, kesimpulannya adalah uji hipotesis di atas yaitu terdapat korelasi antar butir pertanyaan kuesioner perilaku disiplin berlalu lintas pada siswa yang sudah pernah menerima pendidikan lalu lintas.

Nilai r yang dihasilkan dibandingkan dengan $r$ tabel dengan tingkat signifikasi $95 \%(\alpha=0,05)$. Apabila nilai $r$ hitung lebih besar dari $r$ tabel, maka instrumen yang berupa kuesioner yang digunakan dapat dikatakan valid. Nilai $\mathrm{DF}$ pada penelitian ini adalah $\mathrm{DF}=\mathrm{N}-2, \mathrm{~N}$ berjumlah sebanyak 22 responden maka nilai $\mathrm{DF}=20$ dengan tingkat signifikan 0,05 pada uji dua arah diperoleh nilai $r$ table yaitu 0,4227 . Apabila hasil uji validitas menunjukkan $r$ hitung $\geq \mathrm{r}$ tabel, maka Ho ditolak dan Ha diterima artinya butir pertanyaan kuesioner dinyatakan valid.

Tabel 2. Hasil Uji Validitas Perilaku Disiplin Pada Siswa Yang Belum/Tidak Menerima Pendidikan Lalu Lintas

\begin{tabular}{|c|l|c|c|c|c|}
\hline Variabel & \multicolumn{1}{|c|}{ Butir Pertanyaan } & rhitung & rtabel & $\begin{array}{c}\text { Hasil } \\
\text { Hipotesis }\end{array}$ & Keterangan \\
\hline U1 & Berjalan di sisi paling tepi & 0,6292 & 0,4227 & $\begin{array}{c}\text { Ha } \\
\text { diterima }\end{array}$ & Valid \\
\hline U2 & Berjalan kaki di trotoar & 0,4706 & 0,4227 & $\begin{array}{c}\text { Ha } \\
\text { diterima }\end{array}$ & Valid \\
\hline U3 & $\begin{array}{l}\text { Menoleh ke kanan kiri } \\
\text { serta berhenti sejenak } \\
\text { sebelum menyeberang }\end{array}$ & 0,6292 & 0,4227 & $\begin{array}{c}\text { Ha } \\
\text { diterima }\end{array}$ & Valid \\
\hline U4 & $\begin{array}{l}\text { Menyeberang di zebra } \\
\text { cross }\end{array}$ & 0,4390 & 0,4227 & $\begin{array}{c}\text { Ha } \\
\text { diterima }\end{array}$ & Valid \\
\hline
\end{tabular}




\begin{tabular}{|c|l|c|c|c|c|} 
U5 & $\begin{array}{l}\text { Menyeberang jalan saat } \\
\text { kondisi aman }\end{array}$ & 0,6292 & 0,4227 & $\begin{array}{c}\text { Ha } \\
\text { diterima }\end{array}$ & Valid \\
\hline U6 & $\begin{array}{l}\text { Meminta bantuan petugas } \\
\text { atau orang dewasa jika } \\
\text { kesulitan menyeberang }\end{array}$ & 0,5369 & 0,4227 & $\begin{array}{c}\text { Ha } \\
\text { diterima }\end{array}$ & Valid \\
\hline U7 & $\begin{array}{l}\text { Bersepeda di lajur khusus } \\
\text { sepeda }\end{array}$ & 0,8181 & 0,4227 & $\begin{array}{c}\text { Ha } \\
\text { diterima }\end{array}$ & Valid \\
\hline U8 & $\begin{array}{l}\text { Menggunakan helm saat } \\
\text { akan dibonceng sepeda } \\
\text { motor }\end{array}$ & 0,7976 & 0,4227 & $\begin{array}{c}\text { Ha } \\
\text { diterima }\end{array}$ & Valid \\
\hline U9 & $\begin{array}{l}\text { Memakai seat belt saat } \\
\text { berkendara menggunakan } \\
\text { mobil }\end{array}$ & 0.5208 & 0,4227 & $\begin{array}{c}\text { Ha } \\
\text { diterima }\end{array}$ & Valid \\
\hline
\end{tabular}

Dari tabel diketahui bahwa uji validitas yang dilakukan pada butir pertanyaan kuesioner menghasilkan nilai korelasi yaitu $r$ hitung $\geq \mathrm{r}$ tabel, artinya Ho ditolak dan Ha diterima. Sehingga, kesimpulannya adalah uji hipotesis di atas yaitu terdapat korelasi antar butir pertanyaan kuesioner perilaku disiplin berlalu lintas pada siswa.

\section{Perbandingan Penilaian Masing-Masing Responden}

\section{Perilaku Tertib Berlalu Lintas}

Tabel 3. Perilaku Tertib Belalu Lintas pada Siswa

\begin{tabular}{|c|c|c|c|}
\hline \multicolumn{2}{|c|}{$\begin{array}{c}\text { Sudah Mendapatkan } \\
\text { Edukasi }\end{array}$} & \multicolumn{2}{c|}{$\begin{array}{c}\text { Belum Mendapatkan } \\
\text { Edukasi }\end{array}$} \\
\hline Ya & Tidak & Ya & Tidak \\
\hline$(93 \%)$ & $(7 \%)$ & $(82,6 \%)$ & $(17,4 \%)$ \\
\hline
\end{tabular}

Dari tabel diatas menunjukkan perbandingan bahwa siswa yang pernah/mendapatkan edukasi berperilaku tertib lebih tinggi 10,4\% dari pada sisawa yang belum/tidak mendapat edukasi keselamatan lalu lintas.

\section{Pengetahuan dan Pemahaman Lalu Lintas}

Tabel 4. Pengetahuan dan pemahaman Lalu Lintas pada Siswa

\begin{tabular}{|c|c|c|c|}
\hline \multicolumn{2}{|c|}{ Sudah Mendapatkan Edukasi } & \multicolumn{2}{c|}{$\begin{array}{c}\text { Belum Mendapatkan } \\
\text { Edukasi }\end{array}$} \\
\hline Ya & Tidak & Ya & Tidak \\
\hline$(100 \%)$ & $(0 \%)$ & $(93,5 \%)$ & $(6,5 \%)$ \\
\hline
\end{tabular}


Dari tabel diatas menunjukkan perbandingan bahwa siswa yang pernah/mendapatkan edukasi pengetahuan dan pemahaman akan keselamatan lalu lintas lebih tinggi 6,5\% dari pada sisawa yang belum/tidak mendapat edukasi.

\section{Penerapan pendidikan Lalu Lintas Dalam Keseharian}

Tabel 5. Penerapan pendidikan Lalu Lintas Dalam Keseharian Siswa

\begin{tabular}{|c|c|c|c|}
\hline \multicolumn{2}{|l|}{ Sudah Mendapatkan Edukasi } & \multicolumn{2}{c|}{$\begin{array}{c}\text { Belum Mendapatkan } \\
\text { Edukasi }\end{array}$} \\
\hline Ya & Tidak & Ya & Tidak \\
\hline$(95,6 \%)$ & $(4,4 \%)$ & $(85,3 \%)$ & $(14,7 \%)$ \\
\hline
\end{tabular}

Dari tabel diatas menunjukkan perbandingan bahwa siswa yang pernah/mendapatkan edukasi penerapan edukasukasi berlal lintas dalam keseharian lebih tinggi 10,3\% dari pada sisawa yang belum/tidak mendapat edukasi.

\section{PENUTUP}

\section{Kesimpulan}

Berdasarkan anlisis penelitian diketahui bahwa siswa yang telah mendapatkan pendidikan keselamatan berlalulintas dapat memahami praktik dan pemahaman berlalulintas dengan baik dengan nilai rata-rata $93 \%$ untuk prilaku tertib berlalulintas, $100 \%$ untuk penetahuan dan pemahaman lalulintas dan 95,6\%. Berdasarkan anlisis penelitian diketahui bahwa siswa yang tidak mendapatkan pendidikan keselamatan berlalulintas juga dapat memahami praktik dan pemahaman berlalulintas dengan nilai rata-rata $82,6 \%$ untuk prilaku tertib berlalulintas, 93,5\% untuk penetahuan dan pemahaman lalulintas dan 85,3\% menerapakan Pendidikan lalulintas dalam keseharian. Berdasarkan anlisis penelitian diketahui bahwa siswa yang telah mendapatkan pendidikan keselamatan berlalulintas lebih memahami praktik dan pemahaman berlalulintas dibandingkan dengan siswa yang tidak mendapatkan pendidikan keselamatan berlalulintas, meskipun perbandingan nilainya tidak signifikan.

\section{Saran-saran}

Berdasarkan hasil penelitian dan pengolahan data yang telah dilakukan maka dapat dikemukakan beberapa saran yaitu sebagai berikut:

1. Dibutuhkan upaya pengembangan program peningkatan keselamatan lalu lintas pada anak, dengan mempertegas dan menguatkan keyakinan masyarakat tentang manfaat dan risiko serta pemberian contoh yang nyata dari pihak terkait seperti aparat dan pihak yang berwenang. Upaya ini dilakukan agar hasil pendidikan, sosialisasi dan bimbingan yang telah dilakukan tetap tertanam pada perilaku setiap pengguna jalan.

2. Dibutuhkan Diperlukan evaluasi secara rutin terkait pendidikan keselamatan lalu lintas yang telah disosialisasikan, serta diharapkan adanya penegakkan hukum yang tegas kepada setiap pelanggar peraturan lalu lintas melalui kerangka kebijakan, kerangka regulasi dan kerangka konstitusi. 
3. Diperlukan adanya penelitian lanjutan dengan jangka waktu yang lebih panjang untuk mengetahui pola perilaku pada siswa yang sudah pernah mendapatkan edukasi keselamatan berlalu lintas tetap tertanam ketika menganjak remaja ataupun dewasa.

4. Untuk melengkapi faktor-faktor yang belum terungkap dan belum tersampaikan dalam penelitian ini, maka dibutuhkan instrumen penelitian tambahan yaitu dengan metode wawancara mendalam secara langsung kepada orang tua sehingga melibatkan interaksi secara langsung antara peneliti dan objek yang akan diteliti.

5. Kebijakan yang bisa diambil, bisa dengan cara memperbanyak responden atau siswa yang di edukasi dan juga memperbanyak variasi pertanyaan sesusai dengan penelitian tersebut.

\section{Ucapan Terima Kasih}

Ucapan terimakasih disampaikan kepada Prof. Ir. Sigit Priyanto, M.Sc., Ph.D. selaku Dosen Pembimbing Utama. Dr. Eng. Muh. Zudhy Irawan, S.T., M.T. yakni Dosen Pembimbing Pendamping, Dr.Eng. Imam Muthohar, S.T., M.T., D.Eng. selaku Dosen Penguji. Dosendosen dan teman-teman angkatan XXX Magister Sistem dan Teknik Transportasi Universitas Gadjah Mada Yogyakarta yang tidak dapat penyusun sebutkan satu persatu.

\section{DAFTAR PUSTAKA}

1. Ariani, M. 2019. Analisis Faktor Penyebab Terjadinya Kecelakaan Lalu Lintas Pada Anak Usia Sekolah Dasar Di Koka Yogyakarta.

2. Fachrurrozy, 2008. Keselamatan Lalu Lintas (Traffic Safety). Tesis. Yogyakarta: MSTT UGM.

3. Gillham, B., dan Thomson, J.A. 1996. The Challenge of Child Safety Research. London:Routhledge.

4. Meyer, S., et al. 2014. Traffic Hazard Perception Among Children. Transportation Research Part F. hal. 190-198.

5. Priyanto, S. 2003. Materi Kuliah: Keselamatan Lalu lintas. Yogyakarta: MSTT UGM.

6. Wardhana, W. 2009. Panduan Aman Berlalu lintas. Kawah Pustaka, Jakarta.

7. Yuniarti, L. 2018. Penerapan Etika Pendidikan Etika Lalu lintas Dalam Peningkatan Keselamatan Lalu lintas Pada Anak Di Kota Yogyakarta. Tesis. Yogyakarta: MSTT UGM. Zuhriyah, F. 2014. Analisis Keselamatan. 